\title{
Insalubrity in speech therapy and audiology: a brief review
}

\section{Insalubridade em fonoaudiologia: breve revisão}

\author{
Gabriella de Oliveira Ribeiro(1) \\ Maria Isabel de Oliveira e Britto Villalobos ${ }^{(2)}$ \\ Francisnele Maria de Aquino Fraporti Tomáz ${ }^{(3)}$ \\ Paulo Franco Taitson ${ }^{(4)}$ \\ Ana Teresa Brandão de Oliveira e Britto(5)
}

(1) Hospital da Criança de Brasília José Alencar (HCB) - Brasilia, Distrito Federal, Brasil.

(2) Pontifícia Universidade Católica de Minas Gerais (PUC Minas) Departamento de Odontologia - Belo Horizonte, Minas Gerais, Brasil.

(3) Hospital Geral Universitário de Cuiabá (HGU) - Departamento de Odontologia Cuiabá, Mato Grosso, Brasil.

(4) Pontifícia Universidade Católica de Minas Gerais (PUC Minas) - ICBS Belo Horizonte, Minas Gerais, Brasil.

(5) Pontifícia Universidade Católica de Minas Gerais (PUC Minas) Departamento de Fonoaudiologia - Belo Horizonte, Minas Gerais, Brasil.

Source of of support: CAPES

Conflict of interest: non-existent

Received on: March 27, 2017 Accept on: June 15, 2017

\section{Mailing address:}

Maria Isabel de Oliveira e Britto Villalobos Avenida Dom José Gaspar, 500 -

Prédio 46 - Departamento de Odontologia Belo Horizonte, Minas Gerais, Brasil CEP: 30535-901

E-mail: misabel@paces.com.br

\section{ABSTRACT}

Purpose: to expose in a brief discussion the questions about the insalubrity pertinent to speech therapists and audiologists' performance.

Methods: a review of the Portal of Legislation of the Brazilian Federal Government about labor laws, health and health professionals was carried out.

Results: according to NR-15, activities that are above the level of tolerance foreseen in the regulations are considered unhealthy activities, in which the performance of speech-language therapists and audiologists is directly related to the tolerance limits for biological agents.

Conclusion: speech therapists and audiologists as well as several other health professionals present occupational risks in their work. The Brazilian legislation is broad, however, it is necessary to analyze these professionals more deeply with regard to their health.

Keywords: Speech, Language and Hearing Sciences; Occupational Health; Occupational Risks; Bioethics

\section{RESUMO}

Objetivo: expor em uma breve discussão as questões sobre a insalubridade pertinentes a atuação do fonoaudiólogo.

Métodos: foi realizada uma revisão do Portal da Legislação do Governo Federal Brasileiro no que diz respeito às leis trabalhistas, a insalubridade e aos profissionais de saúde. Foram utilizados também, cartilhas e recomendações do Conselho Federal de Fonoaudiologia.

Resultados: de acordo com a NR-15, são consideradas atividades insalubres as que se desenvolvem acima do nível de tolerância previstos na mencionada normativa, em que a atuação do fonoaudiólogo está diretamente relacionada aos limites de tolerância para agentes biológicos

Conclusão: o fonoaudiólogo, bem como diversos outros profissionais da área da saúde, apresenta riscos ocupacionais em sua atuação. A legislação brasileira é ampla, porém, destaca-se a necessidade de analisar com maior profundidade esses profissionais no que tange a saúde desses trabalhadores.

Descritores: Fonoaudiologia; Saúde do Trabalhador; Riscos Ocupacionais; Bioética 


\section{INTRODUCTION}

The term insalubrity is used to define work that is engaged in an environment that is hostile to health, namely, that might put the worker's health at risk'. Currently, one of the main concerns related to occupational health is the insalubrity of the professional ${ }^{1,2}$. The right to insalubrity compensation is recognized only when the activity or operation is included in the regulations of the Ministry of Labor and Employment (MTE) ${ }^{3}$.

Speech therapists and audiologists are constantly in direct or indirect contact with probable sources of contamination. In almost all areas of their expertise (audiology, language therapy, oral motor therapy, and intervention for dysphagia and voice and neurofunctional disorders), these professionals work in unhealthy conditions ${ }^{4,5}$. According to the World Health Organization (WHO), 25\% of the patients who go to doctors' offices carry numerous communicable diseases ${ }^{6}$.

When hiring a speech therapist or an audiologist, every company must respect the Consolidation of Labor Laws (CLL) $)^{2,7}$. The CLL, in its chapter relative to unhealthy or dangerous activities, defines as unhealthy, those conditions that, due to their nature, requirements, or working methods, expose the employees to agents that are harmful and above the tolerance limits due to their nature, intensity, and time of exposure to their effects ${ }^{7}$.

In view of the constant doubts about the right to compensation due to insalubrity and the lack of studies on this topic, the purpose of this paper is to present a brief review of the issues related to unhealthy conditions that are relevant to the performance of speech therapists and audiologists.

\section{METHODS}

The Portal of the Brazilian Federal Government's Legislation concerning labor laws, insalubrity, and health professionals was reviewed, focusing on speech therapists and audiologists. Booklets and recommendations of the Federal Council of Speech Therapy and Audiology were also used.

\section{RESULTS}

Working in unhealthy conditions ensures the employee an additional compensation that is calculated based on the region's minimum wage. It is often equivalent to $40 \%$ for the maximum level of insalubrity, $20 \%$ for intermediate insalubrity, and $10 \%$ for unhealthy conditions of a minimum level ${ }^{8}$. According to the NR-15, all activities that take place above the tolerance level mentioned in the regulation are considered unhealthy activities. Considering this, the activities of a speech therapist are directly related to the tolerance limits for biological agents ${ }^{1}$

The maximum level of insalubrity (40\%) due to exposure to biological risks occurs in works or operations that involve constant contact with patients in isolation for infectious diseases, as well as the objects they use, that are not previously sterilized, because, it is known that tissue, glands, viscera, blood, bones, skin, and excrements carry infectious diseases ${ }^{1}$.

The level of insalubrity is determined by an expert occupational physician or work safety engineer, who examines the activities based on the standards of the MTE. In the case of biological agents, this assessment is done by a qualitative analysis. Permanent work with patients or with infectious-contagious materials in hospitals, emergency services, hospital wards, clinics, vaccination stations, and other institutions for human health care is considered unhealthy at an intermediate level, and it applies only to those professionals who come in contact with patients or handle objects used by patients that are not previously sterilized ${ }^{1}$. Accordingly, a speech therapist/audiologist's work is directly related to unhealthy conditions.

\section{DISCUSSION}

Many workers confuse health hazard allowance with risk compensation, and therefore, they fail to identify such advantages and avail their rights. Pregnant or lactating women and minors cannot perform unhealthy and/or dangerous activities. It is important to clarify that the health hazard allowance and the compensation for risk have a transitory character, i.e., in case the employee stops performing the unhealthy or dangerous activity, the right to compensation ends. Therefore, these may be combined and paid spontaneously paid to workers. However, this does not happen in practice.

The tasks of a speech therapist/audiologist involve the promotion, protection, and recovery of health in the various aspects of human communication: oral and written language, voice, fluency, speech articulation, hearing, balance, orofacial myo-function, cervical system, and swallowing, when operating in the basic care services ${ }^{4-6,9}$.

However, the tasks of a speech therapist/audiologist may be a more integral when performed in more complex health care units. For instance, in home care, a 
speech therapist would be involved in the rehabilitation of people with permanent or transitory disabilities, who require continuous assistance ${ }^{1}$.

Human life has value by itself, regardless of the conditions it is in. We cannot fall into a utilitarian conception of human life by reducing it to the ability to make and produce, forgetting about care and attention. The diseases and cases that determine physiological limitations do not imply that one human being is better than another. Human life is sacred; it has a value that no one can take away, violate, or destroy ${ }^{10}$.

It is known that the exposure to biological agents is impossible to measure in the present time, as its characterization is mostly qualitative. The fact that biological agents are found in the environment characterizes the exposure to such agents, mainly because the transmission of diseases by biological agents is predominantly air borne due to suspended respiratory droplets $^{4,5,9,11}$.

A speech therapist, while working with human communication, will undoubtedly be exposed to oral secretions from the patients, either through simple communication with those patients or through rehabilitation activities that require the emission of sounds by the person being treated. In addition, it is known that a speech therapist is also exposed to other biological agents such as earwax and saliva, and even objects contaminated by these agents ${ }^{5,12}$.

Depending on the specialty of the speech therapist, he/she will be exposed to different secretions. For example, those who work in speech therapy, are exposed to biological agents like earwax and objects contaminated by these agents $\mathrm{s}^{5,12}$. On the other hand, those professionals working with oral and written language, voice, fluency, and articulation of speech, are exposed to air borne contamination through respiratory droplets suspended in the air.

Those working in hospitals, such as Intensive Care Units $(\mathrm{ICU})^{13}$, undergo different types of occupational, biological, ergonomic, and physical hazards, such as stress, work overload, noise, lack of sleep, and poor posture, among others ${ }^{13-15}$. The most common diseases related to workers in this sector are musculoskeletal disorders, varicose veins, and stress. Another very common risk is verbal aggression from patients' relatives. Biological hazards are much higher due to more intimate contact with the patients, and they include air borne contamination by respiratory droplets suspended in the air, and exposure to bodily fluids and secretions, among others ${ }^{13-16}$.
As such, it is important that speech therapists and audiologists as well as the entire health care team use appropriate personal protective equipment (PPE) ${ }^{13,16}$.

A speech therapist/audiologist's involvement in purely administrative functions would remove exposure to such risks, and the health hazard allowance for insalubrity would not be due to such professionals. The same applies to other health professionals in management roles, who do not have direct contact with patients. As such, insalubrity by exposure to biological agents becomes null when the role of these professionals does not put them in direct contact with such risks. However, there are other risks in the work environment, for example, exposure to chemical or physical agents, which can justify the addition of the cost of insalubrity2,4,17.

\section{CONCLUSION}

Speech therapists and audiologists, as well as several other health professionals, face occupational hazards while performing their professional duties. The Brazilian law is broad; however, it is necessary to analyze these professions in greater depth to identify the factors that put their health at risk.

\section{ACKNOWLEDGMENTS}

The authors thank the CAPES for funding this project.

\section{REFERENCES}

1. Brasil. Norma regulamentadora 15. Atividades e operações insalubres. Disponível em: http://www. guiatrabalhista.com.br/legislacao/nr/nr15.htm.

2. Bejgel I, Barroso WJ. O trabalhador do setor de saúde, a legislação e seus direitos sociais. Bol. Pneumol. Sanit. 2001;9(2):69-77.

3. Brasil. Lei 8.112 de 11 de dezembro de 1990 . Brasília, 1990.

4. Santos JN, Fernandes CF, Gil MP, Eugênio ML, Mancini PC. Condutas de biossegurança em ambulatório de fonoaudiologia da rede SUS. Distúrb. Comum. 2014;26(1):42-9.

5. Albuquerque MA, Bernardo VRS, Silva LO, Nagib LC, Frota F. Biosafety in Speech, Language and Hearing Sciences. Rev. CEFAC. 2013;15(5):1088-97.

6. Brasil. Agência Nacional de Vigilância Sanitária. Segurança do Paciente em Serviços de Saúde: Higienização das Mãos. Brasília, 2009. 
7. Brasil. Lei 6.514 de 22 de dezembro de 1977. Brasília, 1977.

8. Brasil. Lei 8.270 de 17 de dezembro de 1991. Brasília, 1991.

9. Contribuição da Fonoaudiologia para o Avanço do Sus. Disponível em: http://www.fonoaudiologia.org. br/publicacoes/cartilha\%20sus\%20-\%20final.pdf.

10. Taitson PF, D'Assumpção EA, Berti SM, Almeida OJ. Bioética: vida e morte. Belo Horizonte: Ed. PUC Minas, 2016. 1 recurso online (171 p.). Disponível em: < http://www.biblioteca.pucminas.br/teses/ ebook/Bioetica2 ed.pdf> . Acesso em: 30 jan. 2017.

11. Brasil. Ministério da Saúde. Classificação de risco dos agentes biológicos. Brasília, 2006.

12. Mancini PC, Teixeira LC, Resende LM, Gomes AM, Vicente LCC, Oliveira PM. Medidas de Biosafety precautions in audiology. Rev. CEFAC. 2008;10(4):603-10.

13. Miranda EJP, Stancato K. Riscos à saúde de equipe de enfermagem em unidade de terapia intensiva: proposta de abordagem integral da saúde. RBTI. 2008;20(1):68-76.

14. Preto VA, Pedrão LJ. Stress among nurses who work at the intensive care unit. Rev Esc Enferm USP. 2009;43(4):838-45.

15. Benatti MCC, Nishide VM. Elaboração e implantação do mapa de riscos ambientais para prevenção de acidentes do trabalho em uma unidade de terapia intensiva de um Hospital Univesitário. Rev. Latino-am enfermagem. 2000;8(5):13-20.

16. Ward D. Implementing infection prevention and control precautions in the community. $\mathrm{Br} \mathrm{J}$ Community Nurs. 2017;22(3):116-8.

17. Mauro MYC, Muzi CD, Guimarães RM, Mauro CCC. Riscos ocupacionais em saúde. R Enferm UERJ. 2004;12:338-45. 